\title{
PENGARUH TEKNOLOGI INFORMASI, KEAHLIAN PEMAKAI DAN INTENSITAS PEMAKAIAN TERHADAP KUALITAS INFORMASI AKUNTANSI PADA PT. BANK RAKYAT INDONESIA (PERSERO), TBK MAKASSAR
}

\author{
Andi Azzah Azizah Mirdin \\ Universitas Muslim Indonesia Makassar \\ Email: andiazzahazizah.mirdin@gmail.com \\ Basri Modding \\ Universitas Muslim Indonesia Makassar \\ Email: basrimodding@umi.ac.id \\ Mursalim \\ Universitas Muslim Indonesia Makassar \\ Email: mursalim@umi.ac.id
}

\section{Abstract}

This research is using quantitative study aimed to see the influence of information technologi use, user expertise, and the intensity of usage on the quality of accounting information. The population of this study was PT Bank Rakyat Indonesia (Persero), Tbk, Makassar Branch. The selection of the sample with total sampling methods. The data used in this study of primary data. Data analysis techniques using multiple regression analysis. The results of this study indicate that information technologi use, user expertise, and the intensity of usage have a positive effect and significant on quality of accounting information.

Keyword: Information Technologi Use, User Expertise, The Intensity of Usage, and Quality Of Abstrak Accounting Information

Penelitian ini merupakan penelitian kuantitatif yang bertujuan untuk melihat apakah ada pengaruh penggunaan teknologi informasi, keahlian pemakai, dan intensitas pemakaian terhadap kualitas informasi akuntansi. Populasi dalam penelitian ini adalah seluruh karyawan PT Bank Rakyat Indonesia (Persero), Tbk, Cabang Makassar. Pemilihan sampel menggunakan total sampling. Data yang digunakan adalah data primer. Analisis data menggunakan analisis regresi linear berganda. Hasil penelitian ini menunjukkan bahwa teknologi informasi, keahlian pemakai dan intensitas pemakaian berpengaruh positif dan signifikan terhadap kualitas informasi akuntansi.

Kata kunci: Teknologi Informasi, Keahlian Pemakai, Intensitas Pemakaian dan Kualitas Informasi Akuntansi 
Invoice: Jurnal Ilmu Akuntansi

p-ISSN: 2714-6359 | e-ISSN: 2714-6340

Vol.3, Nomor 1 | Maret, 2021

\section{PENDAHULUAN}

Teknologi informasi saat ini berkembangan dengan sangat cepat, dan dampaknya adalah adanya kemudahan kepada seluruh masyarakat untuk memudahkan kehidupan, baik kehidupan pribadi, maupun kehiudpan professional. Teknologi informasi dapat digunakan untuk berbagai kepentingan, baik yang mendasar maupun yang lebih tinggi.

Informasi selalu menjadi elemen penting dalam aktivitas manusia. Dari waktu ke waktu, informasi selalu di kumpulkan, di analisa, dan di distribusikan menjadi beberapa diferensiasi golongan serta menjadi panduan aktivitas manusia. Tantangan kompetitif lingkungan zaman sekarang, menjadikan informasi sebagai suatu hal yang vital bagi kesuksesan organisasi (Fowzia \& Nasrin, 2011). Informasi membantu organisasi mencapai titik optimalnya; efektivitas dari informasi memudahkan mengidentifikasi pesaing dan menganalisa keuntungan kompetitor lain (Malin, 2004 dalam Hossein Heidari, Javad Moradi, Mohammad Ghahramanizady, Mehrdad Heidari, 2012). Informasi secara tradisional, yang dulu hanya di gunakan sebagai data dasar untuk di olah nantinya.

Pengoptimalan fungsi informasi bisa dilakukan apabila perusahaan mengembangkan informasi tersebut dengan teknologi komputer. Penerapan komputerisasi pada perusahaan menunjang struktur perusahaan untuk semakin berkembang menjadi lebih baik karena memiliki suatu fungsi yang komprehensif. Komputer ialah alat bantu mengolah/mencari informasi akuntansi yang berkarakter relevan (menunjukkan waktu) dan andal (akurat) pada saat yang bersamaan.
Susanto (2013), mengemukakan bahwa perusahaan yang menggunakan informasi secara efektif dapat memperoleh keuntungan diantaranya dalam bentuk kesempatan untuk melakukan sesuatu lebih dulu (lebih cepat), lebih benar (efektif), dan lebih murah (efisien) dibandingkan pesaingnya. Efektivitas dan efisiensi serta pengendalian dapat terwujud melalui penggunaan informasi yang berkualitas yang dihasilkan dari suatu sistem informasi.

Kriteria kualitas informasi adalah relevan, akurat, tepat waktu dan lengkap. Relevansi dari informasi berkaitan dengan kemampuan informasi tersebut dalam mengurangi ketidakpastian dan dapat meningkatkan kemampuan personil para pengambil keputusan serta berhubungan dengan permasalahan yang sedang dihadapi oleh pengguna. Informasi dikatakan akurat apabila data yang dimasukkan dan proses yang digunakan dalam sistem telah sesuai dengan kenyataan (Hall, 2013). Informasi yang tidak memenuhi kriteria kualitas informasi merupakan informasi yang tidak berguna. Ketika sebuah organisasi menggunakan informasi yang tidak berkualitas atau tidak memadai, maka keputusan yang diambil merupakan keputusan yang tidak efektif. Sistem informasi banyak manfaatnya bagi perusahaan, manfaat dari system informasi adalah meningkatkan operasional, memperkenalkan inovasi dalam bisnis dan membangun sumbersumber informasi strategi.

Sistem informasi disini memiliki peran yang sangat penting dalam kaitannya dengan kualitas informasi akuntansi. Semakin berkembangnya sistem informasi yang digunakan, maka 
Invoice: Jurnal Ilmu Akuntansi

p-ISSN: 2714-6359 | e-ISSN: 2714-6340

Vol.3, Nomor 1 | Maret, 2021

informasi yang dihasilkan akan semakin baik pula dan akan memberikan berbagai kemudahan pada kegiatan instansi pemerintah dalam rangka meningkatkan kualitas informasi akuntansinya. Kualitas informasi akuntansi berhubungan dengan banyak factor, tiga di antaranya adalah teknologi informasi, keahlian pemakai, dan intensitas pemakaian.

Sebuah sistem informasi berbasis komputer adalah kumpulan dari berbagai perangkat keras dan perangkat lunak yang mengubah data menjadi informasi yang dapat memberikan manfaat bagi penggunanya. Kebutuhan terhadap informasi tergantung pada berbagai faktor, diantaranya adalah teknologi informasi yang digunakan. Dengan adanya teknologi informasi akan lebih meningkatkan pelayanan yang diberikan instansi pemerintah. Teknologi informasi yang digunakan haruslah teknologi yang up to date agar informasi yang dihasilkan lebih tepat guna. Karena teknologi akan terus mengalami perkembangan dari waktu ke waktu seiring dengan perkembangan zaman. Hasil penelitian dari Rahmi (2013), Dotulong, dkk (2015), Sofianti, dkk (2015), Nofriyanti (2015), Evania (2016), dan Landau (2018) menemukan bahwa teknologi berpengaruh signifikan terhadap kualitas informasi akuntansi. Sementara penelitian Fitriyani (2014), menemukan sebaliknya bahwa teknologi tidak berpengaruh terhadap kualitas informasi akuntansi.

Keahlian pemakai dalam mengoperasikan suatu sistem dapat dilihat dari seberapa besar pengetahuan dan kemampuan yang dimiliki pemakai untuk mengidentifikasi, mengolah, mengakses, dan menginterpretasikan data dalam bentuk informasi akuntansi yang berkualitas. Untuk meningkatkan keahlian pemakai dapat dilakukan dengan berbagai cara. Antara lain melalui pendidikan khusus, pengalaman, dan pelatihan dibidang sistem informasi dan teknologi komputer. Hasil penelitian dari Rahmi (2013), Dotulong, dkk (2015), Nofriyanti (2015), dan Evania (2016), menemukan bahwa keahlian pemakai berpengaruh terhadap kualitas informasi akuntansi. Sebaliknya hasil penelitian dari Fitriyani (2014) dan Landau (2018), menemukan bahwa keahlian pemakai tidak berpengaruh terhadap kualitas informasi akuntansi.

Selain pengguna teknologi yang ahli di bidangnya, intensitas pemakaian dapat menjadi salah satu faktor yang menjadi pengaruh baik atau tidaknya kualitas informasi akuntansi yang dihasilkan oleh suatu sistem informasi. Seberapa seringkah teknologi digunakan untuk menghasilkan suatu informasi, apakah teknologi tersebut telah digunakan dengan maksimal dan apakah penggunaan teknologi informasi tersebut semata-mata hanya untuk menghasilkan informasi akuntansi merupakan pertanyaan-pertanyaan yang akan muncul terkait dengan intensitas pemakaian. Semakin sering pemakai menggunakan teknologi informasi, maka kemungkinan terjadinya kesalahan dapat diminimalisir. Pengguna dapat segera mengetahui jika terjadi kesalahan dan dapat segera diperbaiki. Dengan demikian, informasi yang dihasilkan akan semakin baik. Hasil penelitian dari Evania (2016) dan Landau (2018), menemukan bahwa intensitas pemaiakan berpengaruh terhadap kualitas informasi akuntansi. Sementara Fitriyani (2014), menemukan bahwa 
Invoice: Jurnal Ilmu Akuntansi

p-ISSN: 2714-6359 | e-ISSN: 2714-6340

Vol.3, Nomor 1 | Maret, 2021

intensitas pemakaian tidak berpengaruh terhadap kualitas informasi akuntansi.

Berdasarkan review penelitian terdahulu di atas diketahui adanya research gap berupa inkonsistensi (tidak konsistennya) hasil penelitian. Bahwa tidak selalu kualitas informasi akuntansi ditentukan oleh teknologi informasi, keahlian pemakai dan intensitas pemakaian. Dengan demikian maka penulis tertarik untuk kembali melakukan penelitian tentang pengaruh teknologi informasi, keahlian pemakai dan intensitas pemakaian terhadap kualitas informasi akuntansi dengan mengambil PT. Bank Rakyat Indonesia (Persero), Tbk di Makassar sebagai lokasi penelitian.

Berdasarkan uraian di atas, maka dilakukan penelitian dengan fokus "Pengaruh Teknologi Informasi, Keahlian Pemakai dan Intensitas Pemakaian Terhadap Kualitas Informasi Akuntansi Pada PT. Bank Rakyat Indonesia (Persero), Tbk Makassar."

\section{TINJAUAN PUSTAKA}

Technology Acceptance Model (TAM) Salah satu model yang menjelaskan mengenai tingkat penerimaan terhadap teknologi adalah TAM, yang dikembangkan oleh Davis F.D (1989) dalam Landau (2018), merupakan model yang paling sederhana dan mudah diterapkanserta sering digunakan dalam penelitian teknologi informasi. Tujuan model ini dibangun untuk menjelaskan bagaimana pengguna atau user dapat menerima suatu teknologi dalam sistem informasi dan menjelaskan faktor-faktor utama dari perilaku pengguna teknologi informasi terhadap penerimaan penggunaan teknologi informasi yang digunakan.

\subsection{Theory of Reasoned Action (TRA)}

Suatu teori yang berhubungan dengan sikap dan perilaku individu dalam melaksanakan kegiatan atau tindakan yang beralasan dalam konteks penggunaan teknologi informasi. Seseorang akan memanfaatkan teknologi informasi atau sistem informasi akuntansi dengan alasan bahwa teknologi atau sistem tersebut menghasilkan manfaat bagi dirinya. TRA yang dikembangkan oleh Fishbein (1975) dalam Landau (2018), menyatakan bahwa perilaku pemakai sistem bersamaan dengan norma dan sosial dan faktor situsional lainnya yang memotivasi dalam mengikatkan penggunaan sistem informasi akuntansi sehingga teori ini dapat memprediksi suatu perilaku.

\subsection{Kualitas Informasi Akuntansi}

Informasi akuntansi merupakan output yang dihasilkan oleh suatu sistem informasi akuntansi. Informasi akuntansi inilah yang nantinya akan digunakan dalam pengambilan keputusan. Keputusan yang dimaksud merupakan keputusan ekonomi yang digunakan dalam menentukan pilihan dalam memutuskan tindakan apa yang akan diambil nantinya. Jogiyanto (2015), mengemukakan bahwa informasi ibarat darah yang mengalir di dalam tubuh suatu organisasi, sehingga informasi ini sangat penting di dalam suatu organisasi. Suatu sistem yang kurang mendapatkan informasi akan menjadi luruh.

Informasi memiliki nilai yang berasal pengaruhnya terhadap keputusan. Oleh karena itu, jika informasi tidak meningkatkan atau mempengaruhi keputusan, maka informasi memiliki nilai negatif. Sudirjo (2006) dalam Landau (2018), 
Invoice: Jurnal Ilmu Akuntansi

p-ISSN: 2714-6359 | e-ISSN: 2714-6340

Vol.3, Nomor 1 | Maret, 2021

mendifinisikan informasi sebagai data yang penting yang memberikan pengetahuan yang berguna. Kualitas suatu informasi harus akurat, tepat waktu, relevan dan yang menentukan nilai dari informasi adalah manfaat dan biaya untuk mendapatkan data yang diolah melalui suatu model menjadi informasi, penerima kemudian memberi informasi tersebut, membuat suatu keputusan dan melakukan tindakan, yang berarti menghasilkan suatu tindakan yang lain yang membuat sejumlah data kembali.

Bodnar (1996) dalam Landau (2018), mengemukakan bahwa kualitas informasi umumnya meningkat jika terdapat kondisi-kondisi berikut:

1. Akurasi, informasi benar dalam merefleksikan realitas.

2. Ketepatan waktu, informasi bersifat mutakhir.

3. Waktu tanggap, informasi tersedia dengan cepat.

4. Kelengkapan, informasi berisikan segala sesuatu yang dibutuhkan.

5. Relevan, informasi mempengaruhi keputusan yang dibuat.

Jogiyanto (2015), mengemukakan bahwa informasi yang berkualitas dari suatu sistem informasi tergantung pada tiga hal berikut ini:

1. Akurat, berarti informasi harus bebas dari kesalahan-kesalahan dan tidak bias atau menyesatkan. Akurat berarti informasi harus jelas mencerminkan maksudnya. Informasi harus akurat karena dari sumber informasi sampai ke penerima informasi kemungkinan banyak terjadi gangguan yang dapat merubah atau merusak informasi tersebut.

2. Tepat pada waktunya, berarti informasi yang datang pada penerima tidak boleh terlambat. Informasi yang sudah usang tidak akan mempunyai nilai lagi. Karena informasi merupakan landasan dalam pengambilan keputusan. Bila keputusan terlambat, maka dapat berakibat fatal untuk organisasi.

3. Relevan, berarti informasi tersebut mempunyai manfaat bagi pemakainya. Relevansi informasi untuk tiap-tiap orang satu dengan yang lainnya berbeda.

\subsection{Teknologi Informasi}

Jogiyanto (2015), mengemukakan bahwa teknologi informasi meliputi komputer (mainframe, mini, micro), perangkat lunak, database, jaringan (internet dan intranet), elektronik, dan jenis lainnya yang berhubungan dengan teknologi. Teknologi informasi selain sebagai teknologi komputer (hardware dan software) untuk memproses dan penyimpanan informasi juga berfungsi sebagai teknologi komunikasi untuk penyebaran informasi. Komputer sebagai salah satu komponen dari teknologi informasi merupakan alat yang bisa melipatgandakan kemampuan yang dimiliki dan komputer juga bisa mengerjakan sesuatu yang mungkin manusia tidak mampu melakukannya. Dengan komputer, informasi yang dihasilkan dapat tepat pada waktunya dan tepat nilainya.

Jurnali dan Supomo (2002), mengemukakan bahwa pemanfaatan teknologi adalah tingkat integrasi teknologi informasi pada pelaksanaan tugas - tugas akuntansi, pemanfaatan tingkat integrasi TI pada pelaksanaan tugas-tugas akuntansi terdiri dari:

1. Bagian akuntansi/keuangan memiliki komputer yang cukup untuk melaksanakan tugas; 
2. Jaringan internet telah terpasang di unit kerja;

3. Jaringan komputer telah dimanfaatkan sebagai penghubung antar unit kerja dalam pengiriman data dan informasi yang dibutuhkan;

4. Proses akuntansi sejak awal transaksi hingga pembuatan laporan keuangan dilakukan secara komputerisasi;

5. Pengolahan data transaksi keuangan menggunakan software yang sesuai dengan peraturan perundang undangan;

6. Laporan akuntansi dan manajerial dihasilkan dari sistem informasi yang terintegrasi;

7. Adanya jadwal pemeliharaan peralatan secara teratur; dan

8. Peralatan yang usang/rusak didata dan diperbaiki tepat pada waktunya.

Seiring perkembangan di dalam era globalisasi, teknologi informasi mulai memberikan pengaruh yang besar dalam kehidupan manusia. Teknologi informasi banyak berperan antara lain dalam bidang pendidikan, ekonomi, dan pemerintahan. Dalam bidang ekonomi, pengaruh besar diberikan teknologi informasi pada bidang akuntansi. Salah satu bidang akuntansi yang banyak dipengaruhi oleh perkembangan teknologi informasi adalah Sistem Informasi Akuntansi (SIA). Dampak yang dirasakan secara nyata adalah pemrosesan data yang mengalami perubahan dari sistem manual ke sistem komputer dan bermunculannya software-software untuk akuntansi yang dapat mempermudah dalam membuat laporan keuangan. Beberapa jenis software akuntansi yang ada antara lain Oracle, Microsoft SQL Server, Daceasy, Paeachtree, Zahir Accounting, dan MYOB yang digunakan untuk akuntansi keuangan perusahaan.

\subsection{Keahlian Pemakai}

Pemakai merupakan salah satu faktor penting dalam pengoperasian teknologi dalam suatu sistem informasi. Pemakai (user) adalah orang yang mengoperasikan atau menggunakan teknologi informasi guna menghasilkan output berupa informasi yang nantinya akan bermanfaat bagi pengguna informasi. Untuk menunjang keberhasilan suatu sistem diperlukan pemakai (user) yang dapat mengoperasikan sistem tersebut dengan baik dan benar.

Laudon (2008) dalam Landau (2018), mengemukakan bahwa para pemakai perlu mengetahui dan memahami teknologi informasi yang digunakan perusahaan dalam sistem informasinyall. Apabila pemakai memiliki keahlian dan pemahaman terhadap sistem yang digunakan pemakai akan merasa lebih memiliki sistem yang digunakan itu, sehingga mereka dapat menggunakan sistem dengan baik. Dengan adanya pemahaman yang baik dari pemakai, arus informasi pun akan tersampaikan dan dapat diinterpretasikan dengan baik, serta diharapkan kualitas informasi yang dihasilkan juga baik. Penerapan sistem informasi akuntansi dapat mempertimbangkan pemakai sistem informasi yang diterapkan agar dapat bermanfaat sesuai dengan tugas dan kemampuan pemakai.

Suatu sistem informasi dikatakan berhasil dan berkualitas ketika sistem tersebut dapat menyediakan layanan informasi serta menghasilkan informasi yang berkualitas pula. Informasi yang berkualitas haruslah memenuhi 
Invoice: Jurnal Ilmu Akuntansi

p-ISSN: 2714-6359 | e-ISSN: 2714-6340

Vol.3, Nomor 1 | Maret, 2021

\begin{tabular}{lcll}
\hline \hline $\begin{array}{l}\text { karakteristik } \\
\text { akuntansi. }\end{array}$ kualitatif & informasi & dalam dunia pekerjaan. Saat ini, \\
karakteristik tersebut, maka keahlian & memenuhi & teknologi informasi telah diperkenalkan \\
pemakai menjadi faktor yang sangat & jenjang pendidikan formal tertinggi \\
penting. Keahlian merupakan kombinasi & dengan terus meng-update materi \\
dari pengetahuan yang diperoleh dari & pembelajaran sesuai dengan \\
pendidikan, pelatihan dan pengalaman & perkembangan teknologi informasi, \\
seseorang dalam bidang tertentu yang & khususnya teknologi komputer.
\end{tabular}

digelutinya.

1. Pendidikan

Keahlian dalam menggunakan teknologi informasi, dalam hal ini komputer, dapat diperoleh dari pendidikan yang telah dilalui oleh pemakai. Pendidikan tersebut dapat berupa pendidikan yang diperoleh secara formal maupun pendidikan nonformal. Tinggi rendahnya tingkat pendidikan akan mempengaruhi individu dalam bermasyarakat. Baik cara berfikir, cara berbicara, menyelesaikan masalah, cara bergaul, dan memanfaatkan sumber daya yang ada untuk memenuhi kebutuhannya, termasuk memanfaatkan teknologi informasi yang ada. Semakin tinggi jenjang pendidikan seseorang maka akan semakin tinggi pula tingkat pengetahuan yang diperoleh.

Pendidikan formal merupakan jenjang pendidikan yang berkelanjutan dan masing-masing jenjang tersebut memberikan pengetahuan yang berbeda tingkatannya. Pendidikan formal biasanya ditempuh dalam waktu yang lama dan dilakukan di instansi pendidikan. Jenjang pendidikan formal dimulai dari tingkat Sekolah Dasar (SD), Sekolah Menengah Pertama (SMP), Sekolah Menengah Atas (SMA), Akademi (D3), Sarjana (S1), Magister (S2), dan Doktor (S3). Setelah menempuh pendidikan formal, seseorang akan mendapatkan gelar atau penghargaan berupa ijazah yang akan digunakan

\section{Pelatihan}

Faktor lain yang membuat seseorang menjadi ahli dalam satu bidang adalah pelatihan. Pengetahuan yang diperoleh dari pendidikan saja tidak cukup. Pelatihan perlu dilakukan agar seseorang dapat mengaplikasikan suatu teori yang telah didapat dari pendidikan secara praktis dalam dunia yang digelutinya. Pelatihan dapat dilaksanakan secara berkelanjutan dengan tema yang sama ataupun dilakukan secara berkala dengan tema yang berbeda sesuai dengan fenomena yang sedang berkembang di masyarakat.

Veithzal (2005) dalam Landau (2018), mengemukakan bahwa pelatihan (training) adalah proses sistematis mengubah tingkah laku seseorang untuk mencapai tujuan organisasi. Pelatihan berkaitan dengan keahlian dan kemampuan untuk melaksanakan suatu pekerjaan. Pelatihan membantu pegawai untuk mencapai keahlian dan kemampuan tertentu agar berhasil dalam melaksanakan pekerjaannya.

Oleh karena itu, pelatihan menjadi faktor penting dalam rangka meningkatkan keahlian pemakai teknologi komputer agar dapat bekerja lebih cepat dan tepat untuk meningkatkan kualitas informasi akuntansi yang dihasilkan oleh sistem informasi. 


\section{Pengalaman}

Lamanya seseorang bekerja akan menjadikan orang tersebut terbiasa dalam melakukan suatu pekerjaan, lebih memiliki wawasan dan pengetahuan yang luas, lebih terampil, dan mudah menyesuaikan diri dengan lingkungan pekerjaan. Hal ini terjadi karena dalam menjalani rutinitas pekerjaannya, seorang pegawai atau pemakai teknologi komputer selalu berhadapan dengan hal yang sama yaitu komputer dan aplikasinya. Dari waktu ke waktu pemakai menjadi lebih dalam pemahamannya terhadap teknologi yang dioperasikannya. Serta pemakai dapat terus mengembangkan kemampuannya seiring dengan teknologi informasi yang juga terus berkembang.

Keahlian komputer dapat dikembangkan melalui pendidikan dan pelatihan. Namun kedua hal tersebut tidak maksimal jika tidak disertai dengan pengalaman. Dengan kata lain, keahlian akan lebih maksimal jika pemakai mengkombinasikan ketiganya yaitu pendidikan, pelatihan, dan pengalaman. Setelah mendapatkan pengetahuan melalui pendidikan dan pelatihan, maka pengalaman akan menjadikan pemakai lebih memahami tentang bidang yang digeluti, dalam hal ini teknologi komputer. Hal inilah yang membuat pengalaman menjadi faktor penting penunjang keahlian.

\subsection{Intensitas Pemakaian}

Intensitas berasal dari bahasa latin yaitu intentio yang berarti ukuran kekuatan, keadaan tingkatan atau ukuran intensnya. Intensitas penggunaan dalam teknologi komputer dapat didefinisikan sebagai ukuran atau tingkat penggunaan teknologi komputer untuk menghasilkan informasi. Perkembangan teknologi informasi yang terus terjadi membuat teknologi semakin mudah dipahami dan digunakan. Hal ini juga terjadi pada teknologi komputer yang terus berkembang. Perkembangan komputer sangat signifikan dari waktu ke waktu. Dimulai dari komputer yang menggunakan CPU yang terpisah hingga tablet PC yang lebih praktis dibawa kemana-mana. Perkembangan ini menjadikan komputer lebih akrab di masyarakat dan intensitas pemakaiannya menjadi lebih sering.

DeLone dan McLean (2003) dalam Landau (2018), mengemukakan bahwa kualitas informasi/pengetahuan berhubungan positif dengan kepuasan pengguna. Keterlibatan pengguna merupakan tingkat sejauh mana pengguna merasa terlibat dan berinteraksi dengan menggunakan sistem informasi dalam aktifitasnya untuk memperoleh informasill. Selanjutnya, DeLone dan McLean (2003) dalam Landau (2018), juga menemukan bahwa semakin baik kualitas sistem, maka pengguna akan sering menggunakan sistem tersebut. Pemakaian yang berulang-ulang ini dapat dimaknai bahwa pemakaian yang dilakukan bermanfaat bagi pemakai.

\subsection{Kerangka Konseptual}

Kerangka konseptual ini diharapkan akan memberikan gambaran dan mengarahkan asumsi mengenai variabel-variabel yang akan diteliti. Berdasarkan penjelasan yang telah disampaikan sebelumnya, maka kerangka pemikiran dalam penelitian ini adalah sebagai berikut: 
Invoice: Jurnal Ilmu Akuntansi

p-ISSN: 2714-6359 | e-ISSN: 2714-6340

Vol.3, Nomor 1 | Maret, 2021

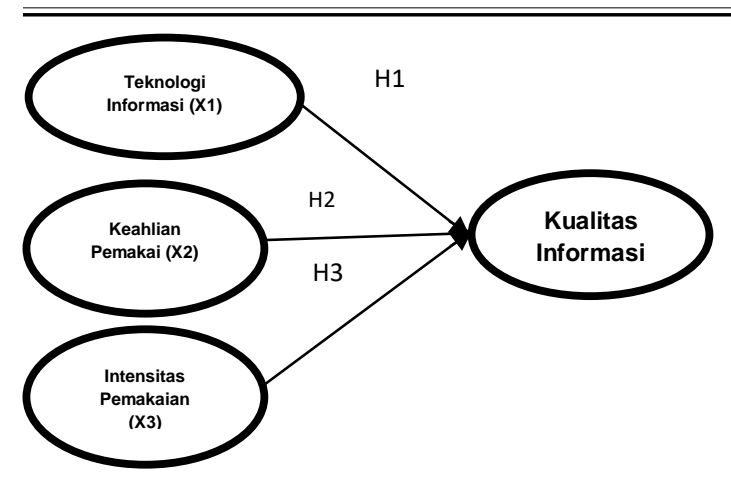

\section{Gambar 1}

Kerangka konseptual

\section{METODE PENELITIAN}

\subsection{Analisis Deskriptif}

Analisis deskriptif adalah suatu metode analisis dimana data-data dikumpulkan, diklarifikasikan, dikelompokkan, selanjutnya dianalisis dan diinterpretasikan secara objektif dalam rangka menerangkan objek tertentu. Penelitian ini menggunakan analisis deskriptif untuk membantu menerangkan hasil temuan penelitian.

\subsection{Uji Instrumen Penelitian}

\section{a. Uji Validitas}

Validitas adalah skala dimana kesimpulan yang dibuat dengan berdasarkan skor menurut angka menjadi sesuai. Pengujian validitas ini menggunakan Total Correlation (Corrected Item), analisis ini dengan caramengkolerasikan masing-masing skor item dengan skor total dan melakukan koreksi terhadap nilai koefisien korelasi yang overestimasi. Pengujian menggunakan dua sisi dengan taraf signifikasi 0,05.

\section{b. Uji Reliabilitas}

Pengujian ini menggunakan metode statistik Cronbach Alpha dengan nilai sebesar 0,06. Apabila Cronbach Alpha dari suatu variabel $\geq 0,6$ maka butir pertanyaan dalam instrumen

penelitian tersebut adalah reliabel atau dapat diandalkan, dan sebaliknya jika nilai Cronbach Alpha $<0<6$ maka butir pertanyaan tersebut tidak reliabel.

\subsection{Uji Asumsi Klasik}

Uji asumsi klasik digunakan untuk mengetahui apakah hasil analisis regresi linier berganda yang digunakan untuk menganalisis dalam penelitian ini terbebas dari penyimpangan asumsi klasik. Uji asumsi klasik yang digunakan dalam penelitian ini meliputi uji normalitas, multikolinieritas, dan heteroskedastisitas. Adapun masingmasing pengujian tersebut dapat dijabarkan secara ringkas sebagai berikut:

\section{a. Uji Normalitas}

Uji normalitas bertujuan untuk menguji apakah dalam suatu model regresi linier variabel terikat dan variabel bebas keduanya mempunyai distribusi normal atau tidak (Ghozali, 2016). Setiap penelitian mengharuskan normalitas data dengan kata lain model regresi yang baik tercermin dari distribusi data normal. Penelitian ini, untuk mendeteksi normalitas data dapat dilakukan dengan pengujian berikut:

1) Histogram

Pengujian dengan model histogram memiliki ketentuan bahwa data normal berbentuk lonceng. Data yang baik adalah data yang memiliki pola distribusi normal. Jika data melenceng ke kanan atau melenceng ke kiri berarti data tidak terdistribusi secara normal.

2) Grafik Normality Probability Plot

Dalam uji ini, ketentuan yang digunakan adalah:

a) Jika data menyebar di sekitar garis diagonal dan mengikuti arah garis 
diagonal, maka model regresi memenuhi asumsi normalitas; dan

b) Jika data menyebar jauh dari diagonal dan/atau tidak mengikuti arah garis diagonal, maka model regresi tidak memenuhi asumsi normalitas.

\section{b. Uji Multikolinearitas}

Uji multikolinieritas bertujuan untuk menguji apakah model regresi mempunyai korelasi antara variabel bebas, dengan kata lainModel regresi yang baik seharusnya tidak terjadi korelasi diantara variabel independen. Dalam hal ini disebut variabel-variabel bebas ini tidak ortogonal.

Dalam mendeteksi ada tidaknya multikolinearitas di dalam model regresi salah satunya dilihat dari:

(1) nilai tolerance dan lawannya; dan

(2) variance inflation factor (VIF).

Kedua ukuran ini menunjukan setiap variabel independen manakah yang dijelaskan oleh variabel independen lainnya. Nilai cut off yang umum dipakai untuk menunjukan adanya multikolinearitas adalah nilai tolerance < 0.10 atau sama dengan nilai VIF $>10$ (Ghozali, 2016).

\section{c. Uji Heteroskedastisitas}

Uji heteroskedastisitas bertujuan menguji model regresi, apakah terdapat ketidaksamaan variance dari residual satu pengamatan ke pengamatan lain. Konsekuensinya adanya heteroskedastisitas dalam model regresi adalah penaksir yang diperoleh tidak efisien, baik dalam sampel kecil maupun besar. Salah satu cara yang dapat digunakan untuk mengetahui ada tidaknya gejala heteroskedastisitas adalah dengan melihat pada grafik scatter plot. Jika ada pola tertentu seperti titik-titik yang membentuk pola tertentu yang teratur (bergelombang, melebar, kemudian menyempit) maka mengindikasikan telah terjadi heteroskedastisitas. Jika tak ada pola yang jelas maka tidak terjadi gejala heteroskedastisitas.

\subsection{Uji Hipotesis}

\section{a. Analisis Regresi Linear Berganda}

Adapun teknik analisis yang digunakan dalam penelitian ini adalah Regresi Linear Berganda. Analisis Regresi Linear Berganda merupakan analisis yang digunakan untuk menguji sejauh mana hubungan sebab akibat antara variable faktor penyebab (X) terhadap variable akibatnya (Y). Model yang digunakan dalam penelitian ini yaitu:

$\mathbf{Y}=\beta_{0}+\beta_{1} \mathbf{X}_{1}+\beta_{2} \mathbf{X}_{2}+\beta_{3} \mathbf{X}_{3}+\ldots \ldots . . \mathrm{e}$

Di mana:

$\begin{array}{ll}\mathrm{Y} & =\text { Kualitas Informasi } \\ & \text { Akuntansi } \\ \beta & \text { Konstanta } \\ \beta_{1}, \beta_{2}, \beta_{3} & =\text { Koefisien } \\ \mathrm{X}_{1} & =\text { Teknologi Informasi } \\ \mathrm{X}_{2} & =\text { Keahlian Pemakai } \\ \mathrm{X}_{3} & =\text { Intensitas Pemakaian } \\ \mathrm{E} & =\text { Error }\end{array}$

\section{b. Uji Koefisien Determinasi (R- Square)}

Koefisien determinasi digunakan untuk melihat seberapa besar variabelvariabel independen secara bersama mampu memberikan penjelasan mengenai variabel dependen dimana nilai $\mathrm{R}^{2}$ berkisar antara 0 sampai $1(0 \leq$ $\left.R^{2} \leq 1\right)$. Semakin besar nilai $R^{2}$, maka semakin besar variasi variabel dependen yang dapat dijelaskan oleh variasi variabel - variabel independen. Sebaliknya jika $\mathrm{R}^{2}$ kecil, maka akan 
semakin kecil variasi variabel dependen yang dapat di jelaskan oleh variabel independen.

\section{c. Uji t}

Uji t digunakan untuk mengetahui apakah variabel independet (X) berpengaruh signifikan terhadap variabel dependen (Y). Pengujian dilakukan dengan taraf signifikansi 0,05. Jika nilai signikansi < taraf signifikan 0,05 maka hipotesis yang diajukan dalam penelitian ini diterima atau dengan kata lain $\mathrm{H}_{\mathrm{a}}$ diterima dan $\mathrm{H}_{0}$ ditolak. Sebaliknya Jika nilai signikansi > taraf signifikan 0,05 maka hipotesis yang diajukan dalam penelitian ini ditolak atau dengan kata lain $\mathrm{H}_{\mathrm{a}}$ ditolak dan $\mathrm{H}_{0}$ diterima.

\section{HASIL DAN PEMBAHASAN}

\subsection{Hasil Penelitian}

a. Uji Validitas dan Uji Reliabilitas

1) Uji Validitas

Pengujian validitas menunjukkan ketelitian serta ketepatan kuesioner yang dibagikan kepada responden. Untuk mengetahui validitas pertanyaan dari setiap variabel, maka rhitung dibandingkan dengan r-tabel. r-tabel dapat dihitung dengan $\mathrm{df}=\mathrm{N}-2$. Jumlah responden dalam penelitian ini sebanyak 75 , sehingga $d f=75-2=73, r(?: 73)=$ 0,191 . Jika r-hitung $>$ r-tabel, maka pertanyaan tersebut dikatakan valid.

Tabel 11

\section{Uji Validitas}

\begin{tabular}{|c|c|c|c|}
\hline Variabel & Item & $\mathbf{r}_{\text {hitung }}>\mathbf{r}_{\text {tabel }}$ & Keterangan \\
\hline \multirow{4}{*}{ Teknologi Informasi (X1) } & 1 & $0,752>0,191$ & Valid \\
\cline { 2 - 4 } & 2 & $0,748>0,191$ & Valid \\
\cline { 2 - 4 } & 3 & $0,780>0,191$ & Valid \\
\cline { 2 - 4 } & 4 & $0,896>0,191$ & Valid \\
\cline { 2 - 4 } & 5 & $0,802>0,191$ & Valid \\
\hline Keahlian Pemakai (X2) & 1 & $0,811>0,191$ & Valid \\
\cline { 2 - 4 } & 2 & $0,847>0,191$ & Valid \\
\cline { 2 - 4 } & 3 & $0,847>0,191$ & Valid \\
\cline { 2 - 4 } & 4 & $0,810>0,191$ & Valid \\
\hline Intensitas Pemakaian (X3) & 1 & $0,799>0,191$ & Valid \\
\cline { 2 - 4 } & 2 & $0,842>0,191$ & Valid \\
\cline { 2 - 4 } & 3 & $0,805>0,191$ & Valid \\
\cline { 2 - 4 } & 4 & $0,836>0,191$ & Valid \\
\hline Kualitas Informasi Akuntansi (Y) & 1 & $0,877>0,191$ & Valid \\
\cline { 2 - 4 } & 2 & $0,793>0,191$ & Valid \\
\cline { 2 - 4 } & 3 & $0,750>0,191$ & Valid \\
\cline { 2 - 4 } & 4 & $0,833>0,191$ & Valid \\
\hline
\end{tabular}

Sumber: Data primer diolah, 2021

Hasil uji validitas menunjukkan bahwa semua item pertanyaan dalam dalam kuesioner adalah valid dan dapat digunakan sebagai alat ukur penelitian.
Hal ini dibuktikan dengan nilai Corrected Item - Total > 0,191. 
Invoice: Jurnal Ilmu Akuntansi

p-ISSN: 2714-6359 | e-ISSN: 2714-6340

Vol.3, Nomor 1 | Maret, 2021

\section{2) Uji Reliabilitas}

Pengujian

reliabilitas

menunjukkan seberapa besar suatu instrument tersebut dapat dipercaya dan digunakan sebagai alat pengumpul data. Reliabilitas instrumen yang semakin tinggi, menunjukkan hasil ukur yang didapatkan semakin terpercaya (reliabel). Penentuan reabilitas instrumen suatu penelitian adalah:

1) Jika cronbach's alpha $<0,6$ maka reabiliti dikatakan buruk;

2) Jika cronbach's alpha 0,6 - 0,8 maka reabiliti dikatakan cukup; dan

3) Jika cronbach's alpha $>0,8$ maka reabiliti dikatakan baik.

Berikut adalah hasil uji reliabilitas atas variable - variabel:

Tabel 12

Uji Reliabilitas

\begin{tabular}{|l|c|c|}
\hline \multicolumn{1}{|c|}{ Variabel } & $\begin{array}{c}\text { Koefisien } \\
\text { Alpha }\end{array}$ & Keterangan \\
\hline $\begin{array}{l}\text { Teknologi } \\
\text { Informasi } \\
\text { (X1) }\end{array}$ & 0,816 & Baik \\
\hline $\begin{array}{l}\text { Keahlian } \\
\text { Pemakai } \\
\text { (X2) }\end{array}$ & 0,851 & Baik \\
\hline $\begin{array}{l}\text { Intensitas } \\
\text { Pemakaian } \\
\text { (X3) }\end{array}$ & 0,846 & Baik \\
\hline $\begin{array}{l}\text { Kualitas } \\
\text { Informasi } \\
\text { Akuntansi } \\
\text { (Y) }\end{array}$ & 0,837 & Baik \\
\hline
\end{tabular}

Sumber: Data primer diolah, 2021

Berdasarkan hasil pengujian

reliabilitas, menunjukkan bahwa semua variabel yang dijadikan instrumen dalam penelitian adalah reliabel dan dapat digunakan sebagai alat pengumpulan data. Sehingga berdasarkan hasil uji reliabil itas diatas, menunjukkan bahwa instrument memiliki tingkat reliabilitas yang tinggi, hal ini dibuktikan dengan nilai koefisien alpha>0,60, jadi hasil ukur yang akan didapatkan dapat dipercaya.

\section{b. Uji Asumsi Klasik \\ 1) Uji Normalitas}

Uji normalitas dilakukan untuk melihat apakah dalam model regresi variabel terikat dan variabel bebas keduanya mempunyai distribusi normal atau tidak. Model regresi yang baik adalah model regresi yang berdistribusi normal. Cara mendeteksi normalitas dilakukan dengan melihat grafik histogram.

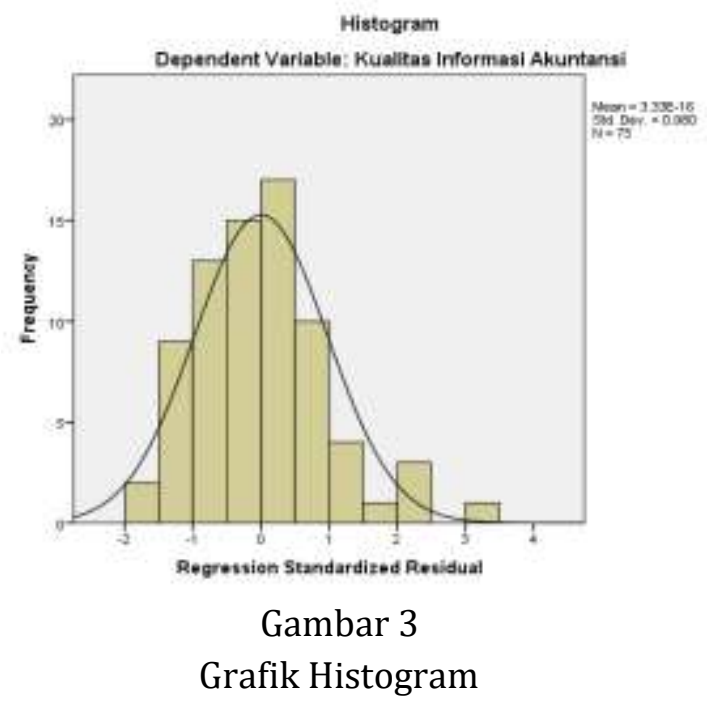

Sumber: Output SPSS, 2021

Berdasarkan grafik histogram diatas, dapat disimpulkan bahwa grafik histogram memberikan pola distribusi yang mendekati normal, hal ini dibuktikan dengan melihat bahwa grafik membentuk simetris dan mengikuti garis diagonal. Akan tetapi grafik histogram ini hasilnya tidak terlalu akurat apalagi ketika jumlah sampel yang digunakan kecil.

Metode yang handal adalah dengan melihat normal probability plot. Pada grafik normal plot terlihat titik-titik menyebar disekitar garis diagonal serta 
penyebarannya mengikuti arah garis diagonal.

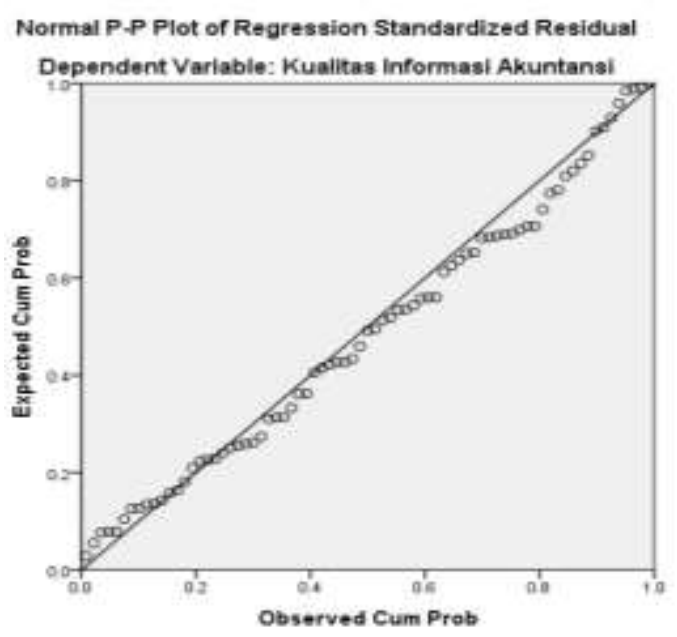

Gambar 4

Normal Prabability Plot

Sumber: Output SPSS, 2021

Berdasarkan grafik normal probability plot, dapat dilihat bahwa titik menyebar disekitar garis diagonal dan penyebarannya mengikuti garis diagonal, sehingga dapat dikatakan bahwa pola distribusinya normal. Melihat kedua grafik diatas, dapat disimpulkan bahwa model regresi dalam penelitian ini dapat digunakan karena memenuhi asumsi normalitas.

\section{2) Uji Heteroskedastisitas}

Heteroskedastisitas menunjukkan bahwa variansi variabel tidak sama untuk semua pengamatan. Jika variansi dari residual satu pengamatan ke pengamatan yang lain tetap, maka disebut homoskedastisitas. Model regresi yang baik adalah yang homoskedastisitas atau tidak terjadi heteroskedastisitas karena data cross section memiliki data yang mewakili berbagai ukuran (kecil, sedang, dan besar). Untuk mendeteksi adanya Heteroskedastisitas, metode yang digunakan adalah metode chart (diagram Scatterplot). Jika:

1) Jika ada pola tertentu terdaftar titiktitik, yang ada membentuk suatu pola tertentu yang beraturan (bergelombang, melebar, kemudian menyempit), maka terjadi Heteroskedastisitas.

2) Jika ada pola yang jelas, serta titiktitik menyebar keatas dan dibawah 0 pada sumbu $\mathrm{Y}$, maka tidak terjadi Heteroskedastisitas.

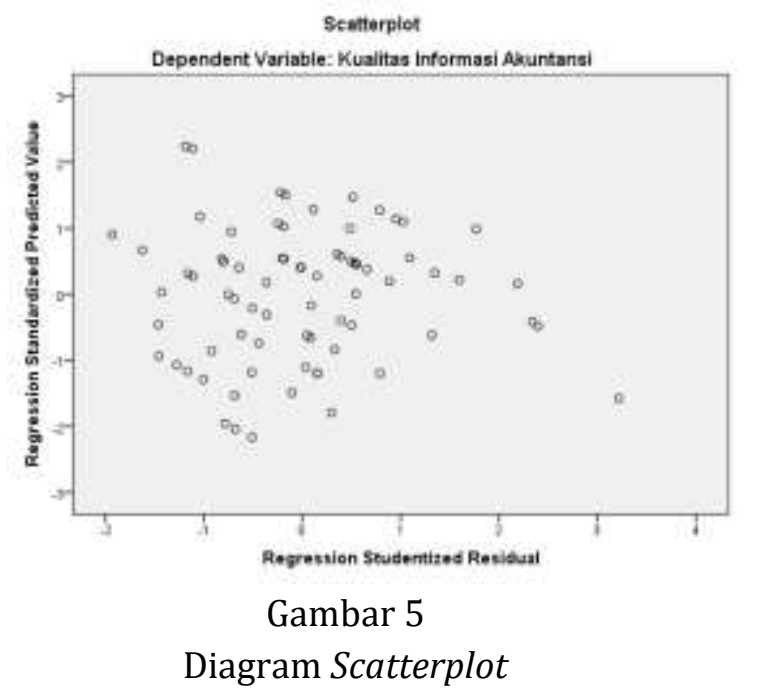

Sumber: Output SPSS, 2021

Berdasarkan diagram diatas, maka dapat dilihat bahwa data tersebar secara acak dan tidak membentuk suatu pola tertentu, hal ini menunjukkan bahwa tidak terdapat heteroskedastisitas. Dengan demikian dapat disimpulkan bahwa terjadinya perbedaan varians dari residual dari suatu pengamatan ke pengamatan yang lain.

\section{3) Uji Multikolinearitas}

Uji Multikolinearitas bertujuan menguji adanya korelasi antara variabel bebas (independent) pada model regresi. Pada model regresi yang baik seharusnya tidak terjadi korelasi diantara variabel. Untuk menguji ada atau tidaknya multikolinearitas dalam model regresi 
Invoice: Jurnal Ilmu Akuntansi

p-ISSN: 2714-6359 | e-ISSN: 2714-6340

Vol.3, Nomor 1 | Maret, 2021

dapat dilihat dari nilai tolerance dan lawannya, yaitu dengan melihat variance inflation factor (VIF). Nilai cut-off yang umum dipakai adalah nilai tolerance 0,01 . Salah satu cara untuk menguji

\section{Tabel 13}

Uji Multikolinearitas

\begin{tabular}{|l|c|c|}
\hline \multicolumn{1}{|c|}{ Variabel } & VIF & Keterangan \\
\hline Teknologi Informasi (X1) & 1,547 & Tidak Multikolinearitas \\
\hline Keahlian Pemakai (X2) & 2,383 & Tidak Multikolinearitas \\
\hline Intensitas Pemakaian (X3) & 2,916 & Tidak Multikolinearitas \\
\hline
\end{tabular}

Sumber: Output SPSS, 2021

Berdasarkan tabel di atass, dapat disimpulkan bahwa model regresi untuk variabel independen yang diajukan oleh peneliti untuk diteliti bebas dari multikolinearitas. Hal ini dapat dibuktikan dengan melihat table diatas yang menunjukkan nilai VIF dari masingmasing variabel independen $<10$, dan dapat digunakan untuk mengetahui pengaruh teknologi informasi, keahlian pemakai dan intensitas pemakaian terhadap kualitas informasi akuntansi.

\section{Tabel 14}

Coefficients

\begin{tabular}{|l|r|r|r|r|r|}
\hline Model & \multicolumn{2}{|c|}{$\begin{array}{c}\text { Unstandardized } \\
\text { Coefficients }\end{array}$} & $\begin{array}{c}\text { Standardized } \\
\text { Coefficients }\end{array}$ & $\mathrm{t}$ & Sig. \\
\cline { 2 - 6 } & \multicolumn{1}{c|}{$\mathrm{B}$} & $\begin{array}{c}\text { Std. } \\
\text { Error }\end{array}$ & Beta & & \\
\hline (Constant) & $\mathbf{. 6 3 0}$ & .252 & & & \\
Teknologi &. $\mathbf{2 0 8}$ & .079 & .237 & 2.632 & $\mathbf{. 0 1 0}$ \\
Informasi & & & & & .015 \\
Keahlian Pemakai & $\mathbf{. 3 5 3}$ & .096 & .412 & 3.690 & $\mathbf{. 0 0 0}$ \\
Intensitas &. $\mathbf{2 5 5}$ & .118 & .266 & 2.155 & $\mathbf{. 0 3 5}$ \\
Pemakaian & & & & & \\
\hline
\end{tabular}

Sumber: Output SPSS, 2021

Berdasarkan tabel Coefficients hasil output SPSS di atas maka diketahui persamaan regresi sebagai berikut:

Dalam persamaan regresi linear berganda di atas dapat dijelaskan secara rinci:

$Y=0,630+0,208 X_{1}+0,353 X_{2}+$

$\mathbf{0 , 2 5 5 X}_{3}$ 
Invoice: Jurnal Ilmu Akuntansi

p-ISSN: 2714-6359 | e-ISSN: 2714-6340

Vol.3, Nomor 1 | Maret, 2021

\section{a) Konstanta ( $\alpha)$}

Konstanta sebesar 0,630. Hal ini berarti jika tidak ada perubahan dari variabel teknologi informasi, keahlian pemakai dan intensitas pemakaian, maka kualitas informasi akuntansi sebesar 0,630 .

\section{b) Teknologi Informasi (X1)}

Nilai koefisien regresi untuk teknologi informasi sebesar 0,208. Dalam penelitian ini dapat dinyatakan bahwa teknologi informasi memiliki pengaruh searah terhadap kualitas informasi akuntasi. Setiap peningkatan variabel teknologi informasi akan memberikan dampak pada meningkatnya kualitas informasi akuntansi sebesar 0,208.

\section{c) Keahlian Pemakai (X2)}

Nilai koefisien regresi untuk keahlian pemakai sebesar 0,353. Dalam penelitian ini dapat dinyatakan bahwa keahlian pemakai memiliki pengaruh searah terhadap kualitas informasi akuntasi. Setiap peningkatan variabel keahlian pemakai akan memberikan dampak pada meningkatnya kualitas informasi akuntansi sebesar 0,353.

\section{d) Intensitas Pemakaian (X3)}

Nilai koefisien regresi untuk intensitas pemakaian sebesar 0,255. Dalam penelitian ini dapat dinyatakan bahwa intensitas pemakaian memiliki pengaruh searah terhadap kualitas informasi akuntasi. Setiap peningkatan variabel intensitas pemakaian akan memberikan dampak pada meningkatnya kualitas informasi akuntansi sebesar 0,208.

\section{e) Uji Parsial (Uji t)}

Uji parsial digunakan untuk mengetahui apakah variabel independet (X) berpengaruh signifikan terhadap variabel dependen (Y). Pengujian dilakukan dengan taraf signifikansi 0,05. Jika Sig>0,05 maka hipotesis yang diajukan ditolak. Sebaliknya Jika Sig.< 0,05 maka hipotesis yang diajukan diterima.

\section{Tabel 15}

Uji t

\begin{tabular}{|l|c|c|c|}
\hline \multicolumn{1}{|c|}{ Varibel } & Sig. $<\boldsymbol{\alpha}$ & Keterangan & Hipotesis \\
\hline Teknologi Informasi (X1) & $0,010<0,05$ & Signifikan & Diterima \\
\hline Keahlian Pemakai (X2) & $0,000<0,05$ & Signifikan & Diterima \\
\hline Intensitas Pemakaian (X3) & $0,035<0,05$ & Signifikan & Diterima \\
\hline
\end{tabular}

Sumber: Output SPSS, 2021

Berdasarkan hasil uji parsial telah dilakukan diketahui bahwa teknologi informasi, keahlian pemakai dan intensitas pemakaian terbukti berpengaruh signifikan terhadap kualitas informasi akuntansi. Dengan demikian maka semua hipotesis yang diajukan dalam penelitian ini diterima.

\section{c. Uji Simultan (Uji F)}

Uji F digunakan untuk mengetahui pengaruh simultan dari semua variabel independet (X) terhadap variabel dependen (Y). Pengujian dilakukan dengan taraf signifikansi 0,05. Jika Sig.>0,05 maka hipotesis yang diajukan ditolak. Sebaliknya Jika Sig.<0,05 maka hipotesis yang diajukan diterima. 


\section{Tabel 16}

Uji F

\begin{tabular}{|l|r|r|r|r|r|}
\hline Model & \multicolumn{1}{|c|}{$\begin{array}{c}\text { Sum of } \\
\text { Squares }\end{array}$} & df & Mean Square & F & Sig. \\
\hline Regressio & 19.241 & 3 & 6.414 & 40.001 & $\mathbf{. 0 0 0}$ \\
$\mathrm{n}$ & & & & & $\mathbf{b}$ \\
$\quad$ Residual & 11.384 & 71 & .160 & & \\
$\quad$ Total & 30.625 & 74 & & & \\
\hline
\end{tabular}

Sumber: Output SPSS, 2021

Berdasarkan hasil uji simultan yang telah dilakukan antara variabel teknologi informasi, keahlian pemakai dan intensitas pemakaian terhadap kualitas informasi akuntansi diketahui bahwa nilai Sig. adalah sebesar 0,000. Nilai tersebut lebih kecil dari derajat kesalahan $(\alpha=0,05)(0,00<0,05)$. Dengan kata lain, teknologi informasi, keahlian pemakai dan intensitas pemakaian secara simultan berpengaruh signifikan terhadap kualitas informasi akuntansi.

\section{d. Uji Determinasi $\left(\mathbf{R}^{2}\right)$}

Analisis koefisien determinasi digunakan untuk mengetahui persentase besarnya pengaruh variabel independen terhadap variabel independen.

Tabel 17

Uji Determinasi

\begin{tabular}{|l|r|r|r|r|}
\hline Model & \multicolumn{1}{|c|}{$\mathrm{R}$} & R Square & $\begin{array}{c}\text { Adjusted R } \\
\text { Square }\end{array}$ & $\begin{array}{c}\text { Std. Error of } \\
\text { the Estimate }\end{array}$ \\
\hline 1 & $.793^{\mathrm{a}}$ & $\mathbf{. 6 2 8}$ & .613 & .40042 \\
\hline
\end{tabular}

Sumber: Output SPSS, 2021

Berdasarkan hasil uji koefisien deteminasi di atas, diketahui bahwa kualitas informasi akuntansi PT Bank Rakyat Indonesia (Persero), Tbk, Makassar, mampu dijelaskan oleh variabel teknologi informasi, keahlian pemakai dan intensitas pemakaian sebesar $\quad 62,8 \%$. Sisanya $37,2 \%$ dari kualitas informasi akuntansi dijelaskan oleh variabel lain yang tidak disertakan dalam penelitian.

\section{Coefficient determination (R-Square)} digunakan untuk mengukur seberapa banyak variabel endogen dipengaruhi oleh variabel lainnya. Chin dalam Ghozali (2011), menyebutkan hasil $\mathrm{R}^{2}$ sebesar 0,67 ke atas untuk variabel laten endogen dalam model struktural mengindikasikan pengaruh variabel eksogen (yang mempengaruhi) terhadap variabel endogen (yang dipengaruhi) termasuk dalam kategori baik. Sedangkan jika hasilnya sebesar 0,33 0,67 maka termasuk dalam kategori sedang, dan jika hasilnya sebesar 0,19 0,33 maka termasuk dalam kategori lemah. Dengan demikian maka model penelitian ini dapat dikategorikan sedang.

\subsection{Pembahasan}

\section{a. Pengaruh Teknologi Informasi Terhadap Kualitas Informasi Akuntansi}

Penggunaan teknologi informasi dapat diartikan sebagai seberapa optimalkah penggunaan teknologi 
Invoice: Jurnal Ilmu Akuntansi

p-ISSN: 2714-6359 | e-ISSN: 2714-6340

Vol.3, Nomor 1 | Maret, 2021

komputer dalam penyusunan laporan keuangan. Berdasarkan hasil penelitian diketahui bahwa teknologi informasi memiliki pengaruh positif terhadap kualitas informasi akuntansi. Hal ini berarti bahwa teknologi informasi merupakan factor pendukung terciptanya informasi akuntansi yang berkualitas. Dengan kata lain, semakin canggih teknologi informasi yang dimiliki PT. Bank Rakyat Indonesia (Persero), Tbk, Makassar, maka akan berdampak pada semakin berkualitas informasi akuntansi yang mereka sajikan.

Sementara itu, hasil penelitian ini juga menemukan bahwa teknologi informasi berpengaruh signifikan terhadap kualitas informasi akuntansi. Hal ini mengindikasikan bahwa teknologi informasi merupakan factor penentu berkualitas dan tidaknya informasi keuangan pada PT. Bank Rakyat Indonesia (Persero), Tbk, Makassar. Penyajian informasi akuntansi haruslah tepat waktu, lengkap, relevan, andal dan dapat dibandingkan. Untuk memenuhi karakteristik tersebut dibutuhkan sumber daya yang memadai, salah satunya adalah teknologi informasi. Informasi akuntansi yang berkualitas dan dapat memenuhi karakteristik kualitatifnya jika dalam proses penyajiannya menggunakan teknologi informasi.

Pengaruh teknologi informasi terhadap kualitas informasi akuntansi dijelaskan oleh teori Technology Acceptance Model (TAM). TAM menjelaskan apabila sistem memberikan manfaat, maka sistem dikaitkan efektif bagi penggunanya. Sajady dan Hashem (2008) dalam Sridarmaningrum (2018), mengemukakan bahwa efektivitas sistem salah satunya didasarkan pada kontribusinya dalam peningkatan kualitas informasi akuntansi.

Hasil penelitian ini sejalan dengan hasil penelitian sebelumnya dari Rahmi (2013), Dotulong, dkk (2015), Sofianti, dkk (2015), Nofriyanti (2015), Evania (2016), dan Landau (2018), yang menemukan bahwa teknologi berpengaruh signifikan terhadap kualitas informasi akuntansi.

\section{b. Pengaruh Kehalian Pemakai Terhadap Kualitas Informasi Akuntansi}

Keahlian pemakai dalam penelitian ini merupakan perilaku dan tindakan yang dilakukan melalui suatu target yang telah ditentukan sebelumnya atau sesuai dengan kemampuan pemakai selama proses penerapan sistem. Berdasarkan hasil penelitian diketahui bahwa keahlian pemakai memiliki pengaruh positif terhadap kualitas informasi akuntansi. Hal ini berarti bahwa keahlian pemakai merupakan factor pendukung terciptanya informasi akuntansi yang berkualitas. Dengan kata lain, semakin ahli pemakai maka akan berdampak pada semakin berkualitas informasi akuntansi yang mereka sajikan.

Sementara itu, hasil penelitian ini juga menemukan bahwa keahlian pemakai berpengaruh signifikan terhadap kualitas informasi akuntansi. Hal ini mengindikasikan bahwa keahlian pemakai merupakan factor penentu berkualitas dan tidaknya informasi keuangan pada PT. Bank Rakyat Indonesia (Persero), Tbk, Makassar. Penggunaan teknologi informasi haruslah didukung dengan pemakai yang ahli di bidang teknologi informasi terutama teknologi komputer. Dengan adanya pemakai yang telah memahami tentang seluk beluk penggunaan 
teknologi komputer maka pekerjaan akan lebih mudah dilakukan. Dengan begitu informasi akuntansi yang disajikan juga lebih baik karena dikerjakan oleh orang yang ahli di bidangnya.

Pengaruh keahlian pemakai terhadap kualitas informasi akuntansi dijelaskan oleh Theory of Reasoned Action (TRA). Teori ini mengatakan bahwa seseorang akan melakukan suatu perbuatan apabila ia memandang perbuatan itu positif dan ia percaya bahwa orang lain ingin agar ia melakukannya. Dalam konteks pemanfaatan teknologi, maka seseorang akan meningkatkan keahliannya dalam menggunakan teknologi informasi dengan tujuan meningkatkan hasil kerjanya.

Hasil penelitian ini sejalan dengan hasil penelitian sebelumnya dari Rahmi (2013), Dotulong, dkk (2015), Nofriyanti (2015), dan Evania (2016), yang menemukan bahwa keahlian pemakai berpengaruh terhadap kualitas informasi akuntansi.

\section{c. Pengaruh Intensitas Pemakaian Terhadap Kualitas Informasi Akuntansi}

Intensitas pemakaian dalam penelitian ini adalah intensitas penggunaan dalam teknologi komputer dapat didefinisikan sebagai ukuran atau tingkat penggunaan teknologi komputer untuk menghasilkan informasi. Berdasarkan hasil penelitian diketahui bahwa intensitas pemakaian memiliki pengaruh positif terhadap kualitas informasi akuntansi. Hal ini berarti bahwa intensitas pemakaian merupakan factor pendukung terciptanya informasi akuntansi yang berkualitas. Dengan kata lain, semakin intens karyawan menggunakan teknologi informasi maka akan berdampak pada semakin berkualitas informasi akuntansi yang mereka sajikan.

Sementara itu, hasil penelitian ini juga menemukan bahwa intensitas pemakaian berpengaruh signifikan terhadap kualitas informasi akuntansi. Hal ini mengindikasikan bahwa intensitas pemakaian merupakan factor penentu berkualitas dan tidaknya informasi keuangan pada PT. Bank Rakyat Indonesia (Persero), Tbk, Makassar. Untuk memenuhi salah satu bentuk relevansi informasi akuntansi yaitu tepat waktu. Di mana penyajian informasi harus dilakukan secara tepat waktu agar informasi tersebut dapat memberikan manfaat dalam pengambilan keputusan. Maka seorang pembuat laporan keuangan yang juga merupakan pemakai teknologi komputer harus bekerja memenuhi target tersebut. Apabila seseorang bekerja dengan tuntutan waktu maka intensitas bekerja akan semakin tinggi seiring dengan semakin dekatnya batas waktu penyelesaian pekerjaan. Bagi seorang pemakai teknologi komputer, hal ini akan mengakibatkan intensitas pemakaian komputer dalam menyelesaikan laporan keuangan juga akan meningkat. Dimana penggunaan komputer dimaksudkan untuk menyajikan informasi akuntansi.

Hasil penelitian ini sejalan dengan hasil penelitian sebalumnya dari Evania (2016) dan Landau (2018), yang menemukan bahwa intensitas pemaiakan berpengaruh terhadap kualitas informasi akuntansi. 


\section{PENUTUP}

\subsection{Simpulan}

Berdasarkan hasil penelitian dan pembahasan pada bab sebelumnya maka simpulan penelitian ini adalah sebagai berikut:

1 Teknologi informasi berpengaruh positif dan signifikan terhadap kualitas informasi akuntansi pada PT Bank Rakyat Indonesia (Persero), Tbk, Makassar.

2 Keahlian pemakai berpengaruh positif dan signifikan terhadap kualitas informasi akuntansi pada PT Bank Rakyat Indonesia (Persero), Tbk, Makassar.

3 Intensitas pemakaian berpengaruh positif dan signifikan terhadap kualitas informasi akuntansi pada PT Bank Rakyat Indonesia (Persero), Tbk, Makassar.

\subsection{Saran}

Berdasarkan simpulan penelitian di atas maka saran yang diberikan adalah sebagai berikut:

1 Dalam rangka meningkatkan kualitas informasi akuntansi, maka pihak PT Bak Rakyat Indonesia (Persero) Tbk perlu memperhatikan teknologi informasi, keahlian pemakai dan intensitas pemakaian. Hal ini didasarkan pada temuan penelitian di mana ketiga factor tersebut terbukti menjadi factor penentu berkualitas dan tidaknya informasi akuntansi.

2 Penelitian ini hanya menggunakan variabel yaitu Penggunaan Teknologi Informasi, Keahlian Pemakai dan Intensitas Pemakaian. Namun, masih banyak faktor-faktor lain yang dapat mempengaruhi kualitas informasi akuntansi. Sehingga diharapkan kepada penelitian selanjutnya diharapkan menambahkan variabel independen lain yang dapat

menjelaskan variabel dependen.

\section{DAFTAR PUSTAKA}

Azhar Susanto. 2013. Sistem Informasi Akuntansi. Bandung: Lingga Jaya.

Dotulong, Ilham dan Niswatin, dan M. Valentina. 2015. Pengaruh Penggunaan Teknologi Informasi dan Keahlian Penggunaterhadap Kualitas Informasi Akuntansi (Studi Empiris pada Diler Mobil di Kota Gorontalo), Jurnal Akuntansi Universitas Negeri Gorontalo.

Evania, Nova. 2016. Pengaruh Penggunaan Teknologi Informasi, Keahlian Pemakai dan Intensitas Pemakaian Terhadap Kualitas Informasi Akuntansi (Studi Pada Satuan Kerja Perangkat Daerah Kabupaten Indragiri Hulu), JOM Fekon, Volume 3 Nomor 1, hal 635649.

Fitriyani, Riska. 2014. Pengaruh Penggunaan Teknologi Informasi, Keahlian Pemakai dan Intensitas Pemakaian terhadap Kualitas Informasi Akuntansi, Jurnal Ekonomi dan Bisnis Universitas Bengkulu.

Fowzia, R., \& Nasrin, M. 2011. Appreciation of Computerized Accounting System in Financial Institutions in Bangladesh. World Review of Business Research, I.

Ghozali, Imam. 2016. Aplikasi Analisis Multivariate dengan Program SPSS, Badan Penerbit UNDIP, Semarang.

Hall, James. 2013. Sistem Informasi Akuntansi, Edisi 4, Jakarta:Salemba Empa

Jogiyanto. 2015. 2003. Sistem Teknologi dan Informasi, Yogyakarta: AndiYogyakarta.

Landau, Siti Nurannisa. 2018. Pengaruh Penggunaan Teknologi Informasi, 
Keahlian Pemakai dan Intensitas Pemakaian terhadap Kualitas Informasi Akuntansi pada Satuan Kerja Perangkat Daerah (SKPD) Kota Medan. USU Medan.

Nofryanti. 2015. Pengaruh Penggunaan Teknologi Informasi dan Keahlian Pemakaiterhadap Kualitas Informasi Akuntansi dan Dampaknya terhadap Kinerja Organisasi, Jurnal Ekonomi dan Bisnis Universitas Pamulang, Volume 3 Nomor 1, hal 644-655.

Rahmi, Mardiah. 2013. Pengaruh Penggunaan Teknologi Informasi dan Keahlian Pemakai terhadap Kualitas Informasi Akuntansi, Jurnal Akuntansi Universitas Negeri Padang.

Sofianti, Diamonalisa and Nurhayati, Nunung and Neisya. 2015. Effects on Information Technology and Organizational Culture on the Performance of Accounting Information Systems (Survey in Bank " $X$ " Branch Offices in Bandung), European Journal of Accounting, Auditing and Finance Research, Volume 3 Nomor 9, hal 65-73.

Sridarmaningrum, L. G. 2018. Pengaruh Efektivitas Penerapan Sistem Informasi Akuntansi, Kesesuaian Tugas, Kenyamanan Fisik Dan Lingkungan Kerja Pada Kinerja Karyawan LPD Di Kota Denpasar. Universitas Udayana, Denpasar.

Sugiyono, 2013. Metode Penelitian Bisnis (Pendekatan Kuantitatif, Kualitatif, Dan R\&D). Bandung: CV Alfabeta. 